\title{
Peter Philander A bridge for the generations
}

Peter Philander graduated from

Medical School at the University of

Cape Town in 1970. He practices

family medicine at Mountain View

Hospital in Las Vegas, Nevada, USA.

Each of us is a bridge from one generation to another, from one time to another and from one place to another. Those were the major themes for my father, Peter John Philander, during a long and distinguished life.

He spanned the time from just after the end of the First World War until early in the $21^{\text {st }}$ century and during that period he moved from Caledon, a dusty little town in the Cape, from a house without running water or electricity, to Las Vegas, arguably the most modern city on earth. He reveled in change but he was always aware of being a bridge to the past and to the familiar and his moments of greatest pleasure came when he introduced a new generation to the world he knew.

Loss and grief were familiar to him from a childhood during which an older brother died in his teens and two younger siblings died before school-going age. And then, as a young parent, his two-year-old daughter died in his arms, on the way to the hospital in Caledon. Little wonder that his early poetry is suffused with references to death. The memories remained immediate and he could never talk about his poem, "Haar uitvaart," without becoming tearful. For the last years of her life, he cared for my mother, Alice, and he talked often about death and life hereafter. Religion was important to him but it was not without tensions.

All his life he built bridges to other communities and other places. As a young principal at Schoonspruit High School in Malmesbury, he recruited students from as far afield as the Karoo and then he had to find room and board for them. To stir their imagination, he organized weeklong bus trips around the Cape Province. He bought his first car in 1957 and our family then crisscrossed southern Africa, ranging up into the then Rhodesias, South West Africa and Mozambique. These trips became the inspiration for his poetry. A few nights at the ruins in Zimbabwe with moonlit walks around the ancient structures stirred all our imaginations. Once he settled in North America, he took groups of students back to South Africa, to let them sample the rich and complex culture. In his last days he was planning a trip to Croatia to visit a niece in Vela Luka.

He realized early that the political forces that caused massive social upheaval were beyond his realm because he was a man who functioned at the level of the individual. 
Still, the grand issues fascinated him. The history of Namibia and the role of the Herero enthralled him; especially the way the entire tribe stopped having children as a rebellion against German occupiers. He traveled there with two good friends and that visit inspired Vuurklip (1960). Danie Adonis, one of his companions, also features in Rebunie (2000), his novel set in Calvinia.

He was a man who relished change and new challenges. As a young teacher he moved from Plettenberg Bay to Caledon, to Calvinia, to Genadendal, and along the way he got married and had four children, all before he was thirty. His restless energy found an outlet in studying through correspondence at the University of South Afri$\mathrm{ca}$, and in writing poetry. He was the founding principal of two high schools, in Malmesbury and in Cape Town. And while small in stature he dominated situations with his personality.

He started his teaching career in elementary schools and became principal in Calvinia. Once he completed his bachelor's degree, he moved to Genadendal High school. That group of teachers and students became life long friends and they provided the intellectual crucible that allowed him to grow and flourish. The music teacher, Percy Hartzenberg, introduced him to Massenet and his haunting music remained a favorite. Music and poetry were the two supreme arts, in his mind, and all three of his sons studied the piano. We lived in Greyton, a nearby town, because he could not buy a house in the Moravian settlement and we prospered until the tragic death of my sister, Elsa. Partly to escape the emotional tangles that ensnared the family, we moved to Malmesbury, and again he thrived. When he lived in Malmesbury he published his first anthology, Uurglas (1955), after writing had occupied him for many years. The new challenge was as principal and with a new school. He assembled his own staff and he had to recruit students from other communities.

Again he encountered some of the constricting effects of religion. The rural population was largely divided between the Sendingkerk and the Anglican Church. Schools were church owned and school income was per capita, based on student registration. In Calvinia this had led to tremendous strife and the violence he described in Rebunie. In Malmesbury he felt it necessary to attend the Sendingkerk because the pastor was the head of his school board. During this time he wrote and staged a play about Napoleon's exile to Elba and his poetry flourished. He reached out to Dirk Opperman and other writers but the contacts were mostly in writing. Publication of a new poem or a new book was greeted with a calm exuberance because these were experiences nobody else in our family's circle could really share.

A move to Cape Town, when the opportunity arose, was in part motivated by the fact that we three children would soon be going to university. The city provided a departure from the Afrikaans environment in which we had lived until then and the family would now have to function nearly totally in English. To nurture the language, our family tradition was that as young children we took turns every evening 
reading from the King James version of the Bible which was kept in a carefully crafted stinkhout box. We built a house in Rondebosch and he called it Herero. The tribe's name means "I came to stay" and this was chosen in the face of the newly conceived Group Areas Act.

For the first time he joined a community of writers with whom he could socialize and who came to dinner, and to long discussions. S.V. Peterson, a fellow writer lived around the corner and they became close friends. Jan Rabie, Uys Krige, Abraham de Vries and other writers were frequent guests, along with H.W. van der Merwe, the sociologist at the University of Cape Town. His collaboration with Amos Langdown, a former pupil, led to their publication, Die bruin kokon (1965). Nic Olivier at Stellenbosch University was a frequent guest, and host. Adam Small was starting to publish.

Apartheid became an ever more constricting and strangling force during that time and while the move to Cape Town brought some relief from the choking closeness and intimacy of small towns, a larger, freer world beckoned. He and my mother traveled to America and Europe in 1961 and that trip laid the seeds for the family's subsequent emigration. The United States was entering the era of civil rights reform and segregation was being dismantled. The two countries were both at crossroads but they were headed in radically different directions.

Looking back at reviews from those days, one is struck by the invariable reference to the kleurling or coloured poet, writer, artist, educator, student. The headlines incorporated race as the first adjective. But in our household, strenuous efforts were made to avoid the label. We lived within an island in the larger community and we crossed between the different groups. It was impossible to ignore race, but as far as they could, my parents made race irrelevant. All three sons attended UCT, an "integrated" university, but the process became more complex and by the time I, the youngest child, attended, a license had to be obtained from "The Minister", and then it was only granted for study of specific subjects such as medicine and engineering. The Group Areas Act was also being tightened and notice was received that our family would have to sell Herero and move to an "appropriate area." George, my eldest brother, had left for Harvard on a Fulbright scholarship and my second brother, Dennis, was in Minneapolis doing a residency in psychiatry. In March 1969 P.J. Philander and his wife left for New York.

My mother thrived in her new environment where she was freed from the need to protect her family from the onslaught of apartheid. My father, on the other hand, found it more difficult to reconcile to a country that fostered endless second and third opportunities. He worried that life did not have enough worsteling. Teaching was too easy... each teacher designed a curriculum and there was no central inspector who came to visit, no end of year exam, no matriculation and no exempted pass to attend university. It took him many years to reconcile himself to the relaxed, innovative and individualistic school system. 
He made trips to South Africa with groups of his new American students and he cultivated additional friends there. In his lifelong pattern, he arranged for the students to stay with local families and they have now formed lasting bonds between people on the two continents. His poetry took on a new, more cutting political edge with Trialoog (2002), one of his last publications. Rebunie finally appeared after years of editing and rewriting and polishing. It personified his approach to language. He played with words and rolled them around his mouth and off his tongue. Sometimes he used nonsense words and sometimes words from other languages that appealed to his ear. Obrigado, the Portuguese for thank you, was a particular favorite. He had his grandchildren say the word over and over.

He lived in Las Vegas for the last five years of his life. His apartment was filled with Afrikaans books and dictionaries and the collectibles accumulated over a lifetime. A lamp constructed around a gnarled trunk of yellow wood from Knysna shed its light on the stinkhout box. A lamp composed of ostrich eggs that he decorated with black and white sketches of South African scenes lit his study, his desk and his computer.

He is now gone but the bridges that he spent a lifetime constructing and maintaining will persist. Such is the legacy of his personality. And of course his writing will continue to be read and studied and appreciated. These are the rewards of a rich life. 


\section{Lisa Philander Remembering Oupa}

Lisa Philander is a graduate student in Ethnobiology at the University of Kent, Canterbury, United Kingdom. She is currently doing field research in South Africa

Oupa was a different man in Africa. He seemed younger and more relaxed, like you do when you are home. On my first trip to Africa, we took the train through the game reserves in Zimbabwe. I never saw him so excited; he loved the big game animals; he squealed with delight seeing the reflective cat eyes in the night when we went out for a game watch. During the long train trip I questioned Oupa about our family tree and he loved to give me the gossip about who did what, where and when.

Although Oupa was quite determined with his decisions at times, he was also a gentle man, not always an explicit instructor, but he had a subtle way of getting his point across. There were times I went to Oupa - two times that I can recall - when I needed sorting out. Once, when I was at college in Vermont I went to Long Island and again, years later, I went to him in Las Vegas. He was gentle with me. He listened, he didn't say much. He took me to the sea and spoiled me with fancy dinners, which was not his way but mine. He brought me to beautiful places and told me stories that gave me a glimpse into places in his life where he perhaps felt the same way. Maybe he just wanted to distract me, but those were special times for me. It was wonderful to have a place to go where I felt safe and had a wise person to listen to my young life.

On our last trip to Africa, I got to see some of these glory days as we visited a school that he established in Malmesbury. We were there for maybe ten minutes before people from all over town began to show up to see the great Peter Philander. Everyone knew him. He was always extremely humble about such moments, which made it more lovely to witness.

I recall late nights listening to Oupa always working with his words, weighing the options. I wish I had the brilliance that he had with bringing things down to the simplest forms. He made simplicity powerful. This may be the lesson that I learned from him. I have realized that I may be able to continue on a legacy of Oupa's, work in education and promote knowledge in my own way. I would like to think that I could do so with the quiet grace that Oupa did.

Most of the memories I have of Oupa are extremely vivid: the smell of 27 Pershing Avenue, Locust Valley, cedar wood, paper and writing, the carefully placed items, the daily walks, I hear him call my name, I can feel his warm soft hands. Mostly, I see 
glimpses of him when I look at his three sons. I see him walking in a garden the way my Uncle George lingers amongst the plants, I see him try to answer my questions with a story that takes me a few days to decode like my father, Dennis, and I hear him in the writing and laughter of my Uncle Piet.

Obrigado, Oupa. 
Steward van Wyk

Steward van Wyk, is mede-professor in die Departement Afrikaans, Universiteit van Wes-Kaapland. E-pos:svanwyk@uwc.ac.za
P. J. Philander (1921-2006):

'n huldeblyk

Peter John Philander, die tweede oudste seun van John en Suzanna Philander, is op 25 November 1921 op Caledon gebore. Hy voltooi sy laerskoolopvoeding aan die NG Sendingkerkskool op sy geboortedorp waarna hy aan die Opleidingskool Zonnebloem in Kaapstad as onderwyser kwalifiseer. Hy onderwys op Calvinia, Plettenbergbaai, Genadendal en word die eerste skoofhoof van Schoonspruit Hoërskool op Malmesbury en later van Belgravia Hoërskool in Athlone, Kaapstad. In hierdie tyd voltooi hy deur privaatstudie eers sy matriek en later'n BA graad. In 1969 verhuis hy na die VSA waar hy onderwys gee aan'n Kwakerskool op Long Island, New York. Uit sy huwelik met Alice, wat in 1988 oorlede is, word drie seuns gebore. Hy sterf op 7 Februarie 2006 in Las Vegas, Nevada (VSA).

Philander debuteer in 1955 met die digbundel Uurglas. Daarna volg Vuurklip (1960), Die bruin kokon (1965), Zimbabwe (1968), Konka (1978), Venster (1983), Ostrakon (1986) en Trialoog (2002). Hy publiseer ook die kortverhaalbundel Hoefyster vir die hart (1983) en die roman Rebunie (2000). Keurverse,'n bloemlesing van sy gedigte asook dié van S.V. Petersen, word in 1967 deur W.H. Vos saamgestel terwyl Daniel Hugo in 1996 'n verdere bloemlesing byeenbring. Enkele eerbewyse val Philander te beurt onder andere 'n toekenning van die Suid-Afrikaanse Akademie vir Wetenskap en Kuns.

\section{2}

Die uurglasmotief in sy debuutbundel suggereer reeds die historiese aanvoeling wat Philander se gedigte van vroeg af ingee. In 'n aantal epiese gedigte word die strydkragte onderliggend aan die opbloei en (ver)val van groot samelewings belig. In gedigte soos "In sy naam", oor die Romeinse vervolging van die Christene, en "Die hand teen die muur", oor die verval van imperialistiese ryke vanaf die farao's tot koloniale Afrika, word gesuggereer dat die onderdrukte uiteindelik die botoon sal voer.

Ook in "Die slaaf" en "Reliëf" waarin onderskeidelik die geweld van kolonialisme en fasette van wit bevoorregting en swart/bruin ontbering naasmekaar geplaas 
word, wys die smeulende opstand en versugting na bevryding van die onderdrukte, vergelyk:

Wil U met ongerysde brood

en agter skerms met roosterkoek

die onderdruktes groot

en sterk maak wat die vryheid soek.

Soms word die lokale aktualiteit van die verse onderspeel wanneer dit binne' $n$ religieuse raam geplaas word, soos in die slotstrofe van "Jonas":

Moeg van pik en hamer slaan

vir elke dag se skokiaan

lê hy saans alleen en dink

onder die swartgerookte sink

wat wydsbeen oor hom staan in dorp en stad

langs elke vaal verlate pad:

Die Grootbaas het aan hom gesê,

"Ek sal jou môre elders dalk nodig hê."

In die eerste geslag Swart Afrikaanse skrywers waaronder S.V. Petersen en Adam Small, verwoord Philander 'n unieke stem. Met Petersen deel Philander die liriese vers wat die unieke karakter van 'n streek - in sy geval die Overberg en Hantam besing, vergelyk "Aand op Genadendal" of "Veldblomtuin by Caledon". Opvallend in sy liriese verse is die verganklikheidsmotief wat dikwels in die slotstrofe 'n metafisiese dimensie aan die gedig verleen. Soos Small gebruik Philander soms die Ou Testamentiese geskiedenis as interteks om tot die eietydse problematiek te spreek en verwoord hy'n sterk aanklag teen die apartheidsisteem.

Teenoor Petersen se beklaging van rassediskriminasie en Small se satirisering van die stelsel, is daar by Philander'n gerigtheid op die Khoisan voorsate en verbeeld hy 'n geskiedenis van trotse verset teen eeue van onderwerping. Dit kom tot uiting in Vuurklip. Ook hier is die titel aanduidend van'n deurlopende motief; die vuurklip as simbolies van brandpunte in die geskiedenis wat gelei het tot verraad, opstand en bloedvergieting. In epiese vorm word die geskiedenis van Jager Afrikaner, Jonker Afrikaner en Hendrik Witbooi omgedig met as deurlopende motief die sluimering en uitbarsting van opstand teen jarelange verdrukking.

Philander se meelewing met die armes en verdruktes vind verdere gestalte in Die bruin kokon - die bundel gedigte met tekeninge van Amos Langdown wat onlangs deur joernaliste op die voorgrond geplaas is. Hierdie voorstellings doen soms natu- 
ralisties aan en mis die strydvaardigheid van die eerste bundel, vergelyk die reëls "In watter lis is jy vasgevang/ renosterbos (...) hoe kry jy die laaste kink- / el in die tou ooit losgewikkel?"

Zimbabwe handel soos die titel aandui oor hierdie eens magtige ryk in Afrika en sluit aan by die eerste gedigte waarin opbloei en verval'n leimotief is. Die Afrikagerigtheid in die tematiek is uniek in die sestigerjare wanneer die bundel verskyn, veral gemeet aan die invloede op Afrikaanse skrywers van kultuur-filosofiese strominge in Wes-Europa. Met die situering van historiese prosesse binne Afrikakonteks bou Philander voort op'n deurlopende bemoeienis in sy oeuvre.

Polities-betrokke verse wat uit' $n$ historiese moment ontspring en meelewing met die armes en onderdruktes is ook terug te vind in die bundel Konka. Die gedigreeks "Byname" gee hiervan'n aanduiding, so ook die titelvers:

Koulik langs pondokke saans

sit ons om konkas òf wees òf hans;

ruik die kwale van oupa en ouma

in kruie, salwe en doepa

en weet die koue sal duur

lank na hulle vergeet lê buite die kraalmuur.

In Venster is daar'n aantal puntige gedigte met wrang humor oor apartheid, vergelyk: "Boeretroos", "Swarttroos" en "Aparte geriewe"

Weerskante van 'n wit kerkhofmuur

tussen dieselfde sipresse rus

elkeen in sy eie doodskis.

"Onesimus", wat ook in Trialoog herskryf word, bou voort op die deurlopende motief van die slaaf in Philander se werk. Die kontekstualisering in die antieke Griekse tyd strook met Philander se voorliefde vir historiese stof alhoewel die geskiedenisbeeld in hierdie bundel verouderd aandoen en toon dat die digter verwyderd van sy stof is. Dit is veral duidelik in die veronderstelde gesprek tussen swart, wit en bruin wat weens geykthede beeldende krag verloor. Treffender is die korter verse waarin 'n waarneming, herinnering en emosie voor die geestesoog geroep word.

Philander se besonderse aanvoeling vir en bedrewenheid in die poësie vind uiting in sy voorliefde vir vaste versvorme. Hy toon ' $n$ voorliefde vir rym, die ballade, koeplet en sonnet en lewer in hierdie vorme van sy bekendste werke. Hiervan getuig "Sonsverduistering", "Haar uitvaart" en "Maaltyd" - standaardwerke in menige skoolbloemlesing waarmee jong lesers van'n sekere tydvak in die poësie onderrig is.

Philander se sterkste werk verskyn tydens sy verblyf in sy geboorteland. Sy werk 
wat ná 1969 verskyn, toon geringe verdieping en ontginning van nuwe temas. Hierin is opvallend meer nostalgiese herinneringsverse, herdigting van vroeëre temas en herskrywing vanuit'n ouer en oorbekende perspektief wat dan ook veral uitdrukking vind in argaïsmes en ouwêreldse segswyses.

Die kortverhaalbundel Hoefyster vir die hart is 'n voortsetting van aspekte van Philander se digterskap. Die fyn waarneming en liriek in die beskrywing van die landskap en tipes van die Overberg, Suid-Kaap en Boesmanland kry mens in verhale soos "Slang in die Hantam", "Werp jou brood" en "Kaaimansrots". By tye is daar selfs 'n poëtiese ritme soos in die aanvangsreëls van "Distrik Ses". Dit word aangevul met'n goeie aanvoeling vir narratiewe struktuur en intrige. In verhale soos "Moeder", "Kweo" en "Aan die deur" word 'n aantal leimotiewe deurvleg wat uiteindelik ontknoop in 'n verrassende einde wat die broosheid van lewe en mankemente in mens en gemeenskap belig.

Op grond van die inhoud ontspring die bundel uit'n tyd-ruimte (die Wes-Kaap van die 1940's, Noord-Amerika) wat verwyderd is van die sosio-politieke ontstaansgrond (1983) van die teks. Mens kry die indruk dat Philander hier' $n$ vergete leefwyse, dié van die plattelandse en verstedelikte bruin Afrikaanssprekendes van die 1940's, voor die geestesoog wil roep. Die bundel mis egter'n gulde kans om 'n gedurfte perspektief te gee op die intense sosiaal-politieke woelinge soos dit hierdie groep mense in daardie tydvak geraak het, onder andere die politieke beheer van Smuts-Hertzog-Malan, die Tweede Wêreldoorlog. Slegs in enkele verhale soos "Oemfie" en "Granaat" word gelade kwessies soos die ontugtelike verhouding tussen wit en bruin en hul baster-nasate aangeraak. Oorwegend gee die verhale kultuur-historiese inligting oor 'n verbygegane era en sluit aan by vroeër Afrikaanse kontrei- en herinneringsverhale.

Ondanks die feit dat Philander vir meer as drie dekades in Noord-Amerika gebly het, is sy verrekening van hierdie konteks beperk. Oorwegend vorm dié streek die milieu waarbinne verhale oor afskeid en dood, verlies en pyn afspeel. In een verhaal, "Witbroodjie" (opgeneem in Lindeque de Beer se versamelbundel Drif: verhale van menslike drifte, 1997) waag Philander sy hand aan 'n genre uit hierdie wêreld, die plantasieverhaal. In hierdie intrige-belaaide verhaal van Ed en Bekkie en hul verhouding met Massa en Missus word Bybelse parallelle en Indiaanse mitologie ontgin en uiteindelik'n prikkelende blik op seksuele vergrype, verraad en opstand gegee.

Op 79-jarige ouderdom debuteer Philander met Rebunie. Hierdie werk wat as'n outobiografiese vertelling aangebied word, handel oor ' $n$ insident tydens sy jare as skoolhoof op Calvinia. Die verteller, Piet, verhaal die omstandighede waarin die nuutaangestelde onderwyser, Kallie, geesdriftig sy loopbaan begin deur tuinbouprojekte van stapel te stuur om die hongerlydendes te voed, maar algaande verstrengel raak in die kleindorpse politiek van die plaaslike kerke en skole. Kallie se verset teen die ongeskrewe reëls van sy tyd lei daartoe dat hy erg aangerand word en sy lyding as gevolg daarvan word uiteindelik verlig wanneer hy in 'n ongeluk sterf. 
Die roman gaan eweneens gebuk onder'n ouderwetse vertelstyl, argaïese taalgebruik en' $n$ onoortuigende verhaalslot. Die ontginning van intertekste soos die martelaarskap van Christus en Abraham Esau en die simboliek van Rebunie, die vulkaniese krater waaraan die titel ontleen is, gee kompleksiteit aan die verhaal en maak dit 'n belangrike toevoeging tot die veelsydigheid en vakmanskap van die Philander-oeuvre.

Die intense struwelinge tussen gematigde en links-radikale groepe binne die bruin politiek van die veertigerjare is hier die agtergrond waarteen die hooffiguur se kruistog teen onreg afspeel. Die verteller se stigmatisering van linkse groepe soos die Teachers' League of South Africa (TLSA) suggereer Philander se eie sosiaal-politieke posisionering. Sy assosiasie met gematigde leiers soos Charles Golding, sy posisie en rol binne die segregasiepolitiek van daardie tyd onder meer sy deelname aan die Protearadioprogram ('n SAUK-produksie gemik op gekleurdes in die sestigerjare) is enkele aspekte wat dui op Philander se politieke ingesteldheid. Sy betrokkenheid by sulke instansies en praktyke sou gewis die gramskap van links-radikale uitgelok het. En alhoewel Philander buite die aktiewe politiek beweeg het, toon dit aan hoe sy generasie in' $n$ tyd van felle politieke polarisasie teen wil en dank deur die geskille tussen linkse en gematigde groepe geraak is.

3

"Ons wil niks meer hoor omtrent koker, gifpyl en boog, slegs 'n hiep-hiep-hoera vir Piet Philander se trialoog."

So lui die slotstrofe van die openingsgedig "Heildronk" uit Trialoog. Die vers verwoord 'n versugting dat die jare van stryd tot'n einde gekom het en dat dit nou tyd vir gesprekvoering is.

Dis asof Philander daarmee ook sy oeuvre afsluit en op'n ontwapenende, skertsende manier sy huldeblyk vooruit loop. Met sy afsterwe het die Afrikaanse letterkunde'n merkwaardige figuur verloor. 